\title{
Organizacja i funkcjonowanie polskiej służby konsularnej w latach 1945-1949
}

\begin{abstract}
A b s trakt: Organizacja i funkcjonowanie polskiej służby konsularnej po zakończeniu II wojny światowej oparte zostały na przedwojennych przepisach prawa wewnętrznego, by z czasem zastąpić je nowymi normami prawa konsularnego i nowymi strukturami służby konsularnej zarówno w Centrali MSZ, jak i za granicą. Funkcje realizowane przez placówki konsularne w latach 1945-1949, poza rutynowymi administracyjno-organizacyjnymi, polegały na prowadzeniu akcji opiekuńczej w stosunku do polskich obywateli, pomocy w repatriacji i reemigracji, rejestracji szkód wojennych, także współpracy z Polonią.
\end{abstract}

Sło w a klu c z o w e: konsul, służba zagraniczna, prawo konsularne, historia polskiej dyplomacji, polska polityka zagraniczna.

Abstract: Organisation and functioning of the Polish consular service after the end of the World War II were based on the pre-war laws to be replaced in time with new norms and new structures of the consular service, both within the Ministry of Foreign Affairs in Poland and abroad. Functions performed by Polish consular posts in 1945-1949, apart from standard administrative and official ones, consisted mainly in caring for Polish citizens, repatriation and re-emigration operations, registration of war damages, and actions aiming at gaining the Polonia.

Key w or d s: consul, foreign service, consular law, history of Polish diplomacy, Polish foreign policy.

Problem funkcjonowania polskiej służby konsularnej po $1945 \mathrm{r}$. nie został dotąd opracowany w całościowy sposób, a zagadnienia badawcze omówione w literaturze przedmiotu odnoszą się głównie do prawnomiędzynarodowych aspektów jej organizacji lub podejmują analizę organizacyjno-funkcjonalna stanu 
istniejącego po podpisaniu konwencji wiedeńskiej o stosunkach konsularnych z 1963 r. ${ }^{1}$ Dodać należy, że omawiane zagadnienie jest niezmiernie rzadko przedmiotem zainteresowania współczesnych badaczy polskiej polityki zagranicznej, natomiast publikacje powstałe przed rokiem 1989 cechuje tendencyjność i brak obiektywizmu wobec mechanizmów zależności służby zagranicznej od decyzji płynących z kierowniczych gremiów partii rządzącej. Stąd tak częste odwołania do wzorców radzieckich organizacji służby konsularnej i ideologicznego charakteru realizowanych przez nią funkcji².

Podstawową bazę źródłową dla badaczy dziejów polskiej służby konsularnej w omawianym okresie stanowią dokumenty zgromadzone $\mathrm{w}$ archiwum Ministerstwa Spraw Zagranicznych w Warszawie, a zwłaszcza zespoły: Biuro Konsularne i Departament Polityczny oraz dokumenty rządowe opublikowane w Dzienniku Urzędowym MSZ czy Roczniku Służby Zagranicznej Rzeczypospolitej Polskiej.

Należy podkreślić, że działania polskiej służby konsularnej po II wojnie światowej opierały się na przedwojennych przepisach prawa wewnętrznego, jak ustawa o organizacji konsulatów i czynnościach konsulów z 11 XI 1924 r. oraz na konwencjach konsularnych podpisanych przez Polskę w okresie dwudziestolecia międzywojennego ${ }^{3}$. Analiza sprawozdawczości polskich urzędów konsularnych, korespondencji urzędowej Biura Konsularnego MSZ z podległymi placówkami, jak również ustawodawstwa polskiego odnoszącego się do działań placówek konsularnych pozwala na odtworzenie struktur oraz

\footnotetext{
${ }^{1}$ Wśród wydawnictw źródłowych na uwagę zasługuje opracowanie J. Symonidesa, Konwencje konsularne PRL, cz. 1-2, Warszawa 1986; prace odnoszace się do prawnych i organizacyjnych aspektów działania służby konsularnej i dyplomatycznej: K. Bertoni, Praktyka dyplomatyczna i konsularna, Kraków 1947; K. Libera, Zasady międzynarodowego prawa konsularnego, Warszawa 1960; S. Sawicki, Podstawy prawne funkcji konsularnych, na prawach rękopisu, Warszawa 1989; idem, Podstawy prawne funkcji konsularnych, „Sprawy Międzynarodowe" 1990, z. 3, s. 79-90; J. Sutor, Funkcje konsularne w zakresie obrotu prawnego z zagranica, „Palestra” 1978, nr 9, s. 42-49; B. Gabryelska-Straburzyńska, Umowy konsularne w trzydziestoleciu Polski Ludowej, „Sprawy Międzynarodowe” 1975, z. 11, s. 129-135; M. Majewski, Stużba konsularna Polski Ludowej, „Sprawy Międzynarodowe” 1975, z. 11, s. 136-144; Podstawy prawnoorganizacyjne stosunków PRL z zagranica, red. M. Frankowska, Wrocław-Warszawa-Kraków 1983.

2 Archiwum Ministerstwa Spraw Zagranicznych (dalej: AMSZ), z. 23, w. 4, t. 35, k. 170, polskie tłumaczenie radzieckich przepisów konsularnych - Polityczny charakter pracy konsula, zawierające rozróżnienie między konsulem radzieckim a burżuazyjnym. Podkreślono w nich silną polityczną rolę konsula w prawie i praktyce konsularnej ZSRR, pełną podległość obywateli tego kraju przebywających za granica pod jego jurysdykcję oraz ograniczenie ekonomicznych funkcji konsula na rzecz radców handlowych. K. Libera, Prawo konsularne, cz. 1, Warszawa 1951, s. 28-31.

${ }^{3}$ Zbiór przepisów konsularnych MSZ, cz. 1, Warszawa 1929, s. 29-35, Ustawa z dnia 11 XI 1924 o organizacji konsulatów i o czynnościach konsulów; K. Bertoni, op. cit., s. 90-100. Wykaz aktów prawnych nadających uprawnienia konsulom po 1945 r., zob. K. Libera, Prawo konsularne..., cz. 2, s. 41-42.
} 
zakresu zadań realizowanych przez służbę konsularną w trudnym, powojennym okresie. Czystki kadrowe w MSZ prowadzone od 1949 r. oraz zmiany zachodzące w polskiej służbie zagranicznej, będące konsekwencją stalinizacji systemu politycznego w Polsce, spowodowały, że to właśnie ten rok stanowi cezurę zamykająca opracowanie dotyczące struktury i funkcjonowania polskiej służby konsularnej w oparciu o wybrane urzędy konsularne.

Rozwój polskich tradycji konsularnych, wobec braku państwowości od XVIII w., nastapił dopiero po odzyskaniu niepodległości w 1918 r. ${ }^{4}$ Wtedy to, przyjmując za wzór ustawodawstwo francuskie, powstały polskie normy prawne określające zasady funkcjonowania służby konsularnej oraz jej funkcje, podpisano szereg dwustronnych umów konsularnych oraz nawiązano stosunki konsularne z 61 państwami na świecie. Bilans tego okresu dziejów polskiej dyplomacji to funkcjonowanie 261 polskich placówek konsularnych za granica. W 1939 r. Polska posiadała 89 konsulatów zawodowych oraz 142 urzędy honorowe. Pomimo wojennej zawieruchy i problemów z realizacja podmiotowości międzynarodowej udało się zachować trwałość sieci konsularnej, która w 1945 r. stanowiły 72 konsulaty zawodowe i 78 honorowych.

Po zakończeniu II wojny światowej i stopniowym uzyskaniu uznania międzynarodowego przez Tymczasowy Rząd Jedności Narodowej przystapiono do odbudowy struktur polskiej dyplomacji ${ }^{5}$. Na podstawie Tymczasowego Statutu MSZ, opracowanego w lipcu 1945 r., resort składał się z Gabinetu Ministra, Protokołu Dyplomatycznego, Departamentu Politycznego, Departamentu Konsularnego, Departamentu Ogólno-Administracyjnego, Biura Radcy Ekonomicznego, Biura Radcy Prawnego, Biura Prac Kongresowych oraz Biura Szyfrów ${ }^{6}$. Gros spraw związanych z realizacja polityki zagranicznej oraz kontaktami międzynarodowymi zostało skoncentrowanych w Departamencie Politycznym, podzielonym na wydziały według kryterium geograficznego oraz realizującym funkcje propagandowe i informacyjne.

Wspomniany dokument określał także strukturę i zadania Departamentu Konsularnego, działającego pod tą nazwą do marca 1946 r., kiedy to utworzono Biuro Konsularne. Departament składał się z Wydziałów: Ogólnego, Opieki, Administracyjno-Handlowego oraz Paszportowo-Wizowego7. Sprawami urzędów

${ }^{4}$ E.J. Pałyga, Stosunki konsularne Drugiej Rzeczypospolitej, Warszawa 1970, s. 6-197.

5 J. Kukułka, Organizacja polskiej stużby zagranicznej w latach 1944-1989, „Stosunki Międzynarodowe" 2000, nr 1-2, s. 109-112; idem, Dyplomacja polska w latach 1944-1989, w: Historia dyplomacji polskiej $X-X X$ w., red. G. Labuda, W. Michowicz, Warszawa 2002, s. 562-564; K. Szczepanik, Wybrane zagadnienia z zakresu ewolucji struktur organizacyjnych polskiej stużby dyplomatyczno-konsularnej w latach 1944-1989, w: Historia dyplomacji polskiej, t. VI: 1944/1945-1989, red. W. Materski, W. Michowicz, Warszawa 2010, s. 9-42.

${ }^{6}$ AMSZ, Materiały różne, Zarządzenie w sprawie Tymczasowego Statutu Ministerstwa Spraw Zagranicznych; ibidem, Pismo Departamentu Ogólno-Administracyjnego z 13 VII 1945.

7 AMSZ, z. 20, w. 1, t. 1, Organizacja Departamentu Konsularnego MSZ, k.7-9. Nieco inną strukture przedstawia schemat organizacyjny MSZ sporządzony w 1973 r. przez Departament Archiwum i znajdujący się w siedzibie archiwum ministerstwa, na który powołuje się 
konsularnych polskich oraz obcych, tworzeniem konsularnych norm prawnych zajmował się Wydział Ogólny, którego kompetencje obejmowały także politykę migracyjna, legalizację dokumentów oraz przesyłanie instrukcji do polskich urzędów konsularnych ${ }^{8}$. Wydział określał zasady korespondencji, zaopatrywał urzędy konsularne w wydawnictwa urzędowe, kontrolował działalność placówek, organizował zjazdy konsularne, przedkładał wnioski w sprawach budżetowych, zajmował się legalizacją dokumentów. Tak ważne w okresie powojennym kwestie rewindykacji mienia polskich obywateli, ochrony ich praw, udzielania pomocy materialnej oraz załatwianie spraw rentowych, emerytalnych, spadkowych poddane zostały kompetencji Wydziału Opieki. Wydział ten koordynował akcje propagandowe i oświatowe prowadzone za granica przez urzędy konsularne. Wydział Administracyjno-Handlowy nadzorował polskie urzędy konsularne pod względem administracyjnym, prowadził sprawy związane z obywatelstwem oraz sprawy celne, komunikacyjne, handlowe. Udzielaniem wiz wjazdowych, ustalaniem wysokości opłat, a także zasad wydawania paszportów polskim obywatelom za granica zajmował się Wydział Paszportowo-Wizowy. W wyniku zmian w strukturach kierownictwa MSZ w lutym 1946 r. utworzono Biuro Konsularne z Wydziałami: Ogólnym i Paszportowo-Wizowym ${ }^{9}$.

W powojennym okresie funkcjonowania służby konsularnej prace Departamentu, a później Biura Konsularnego, siłą rzeczy koncentrowały się na ustaleniu faktycznego stanu polskiej służby konsularnej i liczebności urzędów na świecie oraz pracy organizacyjno-administracyjnej. Przystapiono także do szkolenia pracowników przed wyjazdem na placówki oraz do działań mających na celu koordynacje pracy placówek konsularnych (Referat Inspekcji Konsularnej, Referat Prawno-Konsularny) w zakresie pragmatyki konsularnej, sprawozdawczości, taryf konsularnych, opracowania zarządzeń dotyczących rejestracji strat wojennych oraz przywrócenia mienia należącego do polskich obywateli ${ }^{10}$. Poza czynnościami normatywnymi załatwiano sprawy rentowe i spadkowe (dużą liczbę odnotowano w Argentynie), legalizowano i wydobywano

w swoich pracach Krzysztof Szczepanik. Według tego źródła na Departament Konsularny składały się Wydziały: Opieki Kulturalnej, Majątkowej i Prawnej, Administracyjno-Handlowy oraz Paszportowo-Wizowy. Por. K. Szczepanik, Dyplomacja Polski 1918-2000. Struktury organizacyjne, Warszawa 2000, s. 129; idem, Wybrane zagadnienia..., s. 42.

8 AMSZ, z. 20, w. 1, t. 1, Okólnik Naczelnika Wydziału Opieki Departamentu Konsularnego z 21 XII 1945, k. 1; ibidem, Organizacja Wydziału Ogólnego Departamentu Konsularnego z 1945, k. 2-3.

${ }^{9}$ Ibidem, Zarządzenie w sprawie przemianowania Departamentu Konsularnego na Biuro Konsularne 14 III 1946, k. 10; ibidem, Schemat organizacyjny Biura Konsularnego z 1946, k. 4 .

${ }^{10}$ Ibidem, t. 7, Sprawozdanie Biura Konsularnego MSZ RP za I półrocze i początek III kwartału 1946, k. 4-23; ibidem, k. 110-112; ibidem, Sprawozdanie Biura Konsularnego MSZ RP za luty 1947, k. 24-42; ibidem, Sprawozdanie z pracy Referatu Prawno-Konsularnego za I półrocze 1949. 
dokumenty, co było szczególnie trudne na terenie ZSRR. Podobne problemy we współpracy z władzami radzieckimi miały Referat Opieki Społecznej oraz Referat Obywatelski i Wojskowy, zajmujące się interwencjami w sprawie aresztowanych Polaków oraz zwolnieniem z Armii Czerwonej bezprawnie wcielonych do niej polskich obywateli czy też uwolnieniem polskich górników wywiezionych do ZSRR, po wkroczeniu Armii Czerwonej na Opolszczyznę a uznanych za Niemców. Działania te napotykały wiele trudności wynikających z braku stosownych dokumentów utraconych w czasie wojny, dlatego Biuro Konsularne zwróciło się do Wydziału Radzieckiego Departamentu Politycznego MSZ z prośbą o doprowadzenie do podpisania z ZSRR umowy dotyczacej pomocy $\mathrm{w}$ zakresie udzielenia informacji na temat zapisów w księgach ludności i rejestrach meldunkowych. Niestety Wydział nie podją inicjatywy, co dodatkowo spowalniało działania na rzecz powrotu polskich obywateli. To właśnie prowadzenie akcji repatriacyjnej i reemigracyjnej polskich obywateli z ZSRR, Mandżurii oraz innych krajów, jak Niemcy, Austria, Belgia, Holandia, Anglia, Kanada, Brazylia, Argentyna, stanowiło najważniejsze zadanie służby konsularnej w omawianym okresie.

Poza czynnościami wynikającymi z aktualnej sytuacji, na którą wpływ miała wojenna zawierucha, pracownicy Biura realizowali rutynowe czynności, wystawiając paszporty (253 służbowe, 1780 zwykłych w okresie od stycznia do października 1946) oraz wizy (160 pobytowych, 567 wjazdowych, 95 dyplomatycznych oraz ponad 300 służbowych ${ }^{11}$. Systematyczne instruowanie placówek w dziedzinie prawa, przepisów konsularnych, wysyłanie Dziennika Urzędowego MSZ, który ukazywał się od maja 1946 r., doprowadziły do większego ujednolicenia pracy urzędów konsularnych. W tej sytuacji polska służba konsularna mogła przejść do innych form działalności, poza organizacyjno-administracyjna, jak sprawy kontaktów z Polonia, które do tej pory zaniedbywano, organizacja życia społecznego i kulturalnego oraz realizacja funkcji w zakresie spraw morskich i gospodarczych. Zalecono urzędnikom konsularnym utrzymywanie stałych i przyjaznych kontaktów z polskimi skupiskami wychodźczymi oraz pracę kulturalna, sugerowano prowadzenie sprawozdawczości polonijnej. Wreszcie rozpoczęto wydawanie Informacyjnego Biuletynu Gospodarczego celem informowania placówek o sytuacji gospodarczej, potrzebach polskiego eksportu i importu oraz stworzenia warunków do rozwoju wymiany handlowej. Nadal jednak brakowało jedności organizacyjnej samego Biura oraz rozgraniczenia kompetencji między nim a innymi jednostkami MSZ ${ }^{12}$. Wiele spraw obywatelskich, dotyczących rent, deportacji, trafiało do innych departamentów politycznych czy terytorialnych MSZ w Warszawie, a dwutorowość działań dezorientowała placówki

\footnotetext{
${ }_{11}$ Wizy (akty prawne o cudzoziemcach w polskiej praktyce konsularnej 1918-1998). Wybór, wstęp i oprac. A. Wasilewski, Warszawa 2003, s. 88-94.

12 AMSZ, z. 20, w. 1, t. 1, Biuro Konsularne - struktura i działania, k. 201-221.
} 
zagraniczne, które często także powielały pracę, kiedy dyplomaci wykonywali czynności konsulów. Krytykowano działania Wydziału ds. Polonii za zbytnia samodzielność i brak przepływu informacji do innych struktur MSZ, które mogłyby korzystać z jego sprawozdawczości. Postulowano rozbudowę Referatu Inspekcji Konsularnej celem kontroli urzędów konsularnych. Podobne problemy z ujednoliceniem pracy występowały na placówkach zagranicznych, o czym świadczy decyzja ambasadora RP we Francji, Stanisława Skrzeszewskiego o utworzeniu w ambasadzie stanowiska inspektora konsulatów ${ }^{13}$. Z uwagi na fakt wydawania przez różne komórki organizacyjne MSZ, bez uzgadniania z Biurem Konsularnym, zarządzeń i okólników dotyczących pracy urzędów konsularnych, zobowiązano wszystkie jednostki do przekazywania do Biura odpisów zarządzeń, instrukcji i okólników, jak również do uprzedniego uzgadniania ich treści ${ }^{14}$.

W omawianym okresie struktura Biura ulegała jeszcze kilkakrotnie zmianom i w maju 1948 r. w jego skład wchodziły Wydziały: Ogólny, ds. Polonii Zagranicą (działające wcześniej w strukturze Departamentu Prasy i Informacji MSZ), ds. Repatriacji i Reemigracji oraz Samodzielny Referat Paszportów Konsularnych i Wizowych, a w 1950 r. dodatkowo wprowadzono Referat Zażaleń oraz przemianowano Wydział ds. Repatriacji i Reemigracji na samodzielny referat, natomiast utworzono Wydział Paszportów Konsularnych i Wiz w miejsce istniejącego referatu ${ }^{15}$. Zmiany w strukturze Biura, podobnie jak w całej służbie zagranicznej, odzwierciedlały aktualne cele i priorytety polityki zagranicznej państwa, ale niewątpliwie były także odbiciem sytuacji wewnętrznej w kraju.

Do lutego 1946 r. Departamentem Konsularnym kierował Mieczysław Rogalski, a jego zastępcą był Stanisław Osóbka, pełniący też funkcję naczelnika Wydziału Ogólnego ${ }^{16}$. Pod koniec 1946 r. dyrektorem Biura Konsularnego

${ }^{13}$ Ibidem, w. 38, t. 456, Protokół z kontroli działalności Konsulatu Generalnego RP w Paryżu przeprowadzonej w dniach 9-18 VI 1946, k. 130.

14 Dz.Urz. MSZ z 1947 r. Nr 5 poz. 65, Koordynacja zarządzeń w sprawach konsularnych w centrali MSZ 8 XI 1947.

15 AMSZ, z. 20, w. 1, t. 1, Zarządzenie ministra spraw zagranicznych z 14 maja 1948 roku, k. 15; Dz.Urz. MSZ z 1948 r. Nr 7 poz. 51, Informacja o zniesieniu Wydziału Polonii Zagranicznej w Departamencie Prasy i Informacji, 15 V 1948 roku; ibidem, poz. 52, Informacja o ustanowieniu Wydziału ds. Polonii Zagranica w Biurze Konsularnym MSZ; AMSZ, z. 20, w. 1, t. 1, Zarządzenie ministra spraw zagranicznych z 31 III 1950 znoszące Wydział ds. Repatriacji i Reemigracji i ustanawiajace Samodzielny Referat ds. Repatriacji i Reemigracji, k. 25; Dz.Urz. MSZ z 1951 r. Nr 1 poz. 3, Zarządzenie w sprawie zniesienia Samodzielnego Referatu Paszportowo-Konsularnego, 31 I 1950.

16 AMSZ, z. 20, w. 1, t. 1, Organizacja Departamentu Konsularnego MSZ do 14 II 1946, k. 7-8; M. Golon, Moskwa, Kijów, Mińsk, Leningrad, Wilno... Problem utworzenia i dziatalności polskich placówek konsularnych w ZSRR w latach 1944-1972, w: Polska polityka wschodnia w XX wieku, red. M. Wojciechowski, Z. Karpus, Włocławek-Toruń 2000, s. $210-212$. 
został Osóbka, a jego zastępca - Michał Jachnis pełniący jednocześnie funkcję Generalnego Inspektora Urzędów Konsularnych. Zmiany kadry kierowniczej Biura Konsularnego zaszły w grudniu 1947 r. i jego kierownictwo obją Mieczysław Broniatowski, wicedyrektorem został Leon Szybek. W 1946 r. w Biurze zatrudniano w sumie 28 osób, co nie wydaje się liczbą przesadnie duża, zważywszy na ogrom pracy konsularnej i liczbę polskich urzędów konsularnych, których w lipcu 1946 r. było $40^{17}$.

W powojennym okresie tworzenia lub odtwarzania struktur polskiej służby konsularnej zatrudniano w niej: 97 pracowników etatowych, 262 kontraktowych oraz 48 niższych funkcjonariuszy ${ }^{18}$. Personel służby konsularnej składał się częściowo z przedwojennych pracowników, jednak gros stanowili nowo zatrudnieni pracownicy, nieposiadajacy odpowiedniego przygotowania merytorycznego czy kompetencji językowych. Zdarzały się przypadki przyjmowania do pracy na podstawie ustnych umów. Nic więc dziwnego, że za jedno z najpilniejszych zadań uznano zapewnienie urzędom konsularnym odpowiedniego personelu, czemu miały służyć trzymiesięczne szkolenia organizowane przez Biuro Konsularne, oraz ustanowienie kontroli ze strony Biura nad ruchami kadrowymi i zatrudnianiem pracowników ${ }^{19}$. Jeśli dodać do tego fakt, że personel konsularny za granica był zbyt szczupły, to trudno wyobrazić sobie, aby urzędy konsularne RP funkcjonowały należycie, zważywszy na ich charakter pracy, wymagajacy często przygotowania prawniczego i ekonomicznego.

Problemy wynikajace z braku wykwalifikowanej kadry urzędniczej dotyczyły całej służby dyplomatycznej po 1945 r. Dlatego resort spraw zagranicznych jako pierwszy przystapił do organizacji szkoleń dla pracowników i kandydatów do służby dyplomatyczno-konsularnej. We wrześniu 1945 r. rozpoczęła działalność Szkoła Konsularno-Dyplomatyczna realizująca kursy języków obcych oraz wykłady z zakresu prawa międzynarodowego, cywilnego, historii, geografii politycznej i gospodarczej, pragmatyki dyplomatycznej

${ }_{17}$ Rocznik Stużby Zagranicznej Rzeczypospolitej Polskiej, stan na 15 XII 1946, Warszawa 1946, s. 11-12. Liczba pracowników Biura wzrosła do ponad 80 osób w połowie 1947 r., Rocznik Stużby Zagranicznej..., stan na 1 VI 1947, s. 13-14; Dz.Urz. MSZ z 1946 r. Nr 2 poz. 37, Wykaz urzędów zagranicznych RP z dnia 1 VII 1946; Wykaz urzędów konsularnych zawarty w Dzienniku Urzędowym MSZ różni się od podanego w sprawozdaniu z listopada Biura Konsularnego, gdzie wykazano istnienie 56 urzędów konsularnych. Różnice dotyczą także stanu zatrudnienia w Biurze Konsularnym, które według sprawozdania Biura z listopada 1946 r. wynosiło 75 osób. Por. AMSZ, z. 20, w. 1, t. 7, Sprawozdanie Biura Konsularnego MSZ RP za I półrocze i początek III kwartału 1946, k. 4-5.

18 Ibidem, Wykaz spraw załatwionych w I półroczu i początku III kwartału 1946, k. 103; ibidem, Sprawozdanie Biura Konsularnego MSZ RP za I półrocze 1946, k. 4; ibidem, z. 20, w. 38, t. 456, Spostrzeżenia i uwagi z lustracji placówek w Danii, Belgii, Francji i Szwajcarii 11 V 1946, k. 6-7; M. Majewski, op. cit., s. 138.

${ }_{19}$ AMSZ, z. 20, w. 1, t. 7, Sprawozdanie Biura Konsularnego MSZ RP za luty 1947, k. 24-42; ibidem, Sprawozdanie Biura Konsularnego MSZ RP za maj-lipiec 1947, k. 58; ibidem, Sprawozdanie Biura Konsularnego MSZ RP za III kwartał 1949, k. 112. 
i konsularnej oraz wychowania politycznego ${ }^{20}$. Poza tym przyszłe kadry zdobywały wykształcenie podczas studiów na Wydziale Dyplomatyczno-Konsularnym Akademii Nauk Politycznych, gdzie pracowali znawcy prawa międzynarodowego i dyrektorzy MSZ: Karol Bertoni i Julian Makowski. W 1950 r. Akademię zastapiła Szkoła Główna Służby Zagranicznej, która istniała do 1959 r., stanowiąc kuźnię kadr dla służby zagranicznej Polski Ludowej. Napływ młodej kadry nie wpłynął jednak znacząco na zwiększenie liczby osób z wyższym wykształceniem zatrudnianych w korpusie służby zagranicznej, skoro w 1956 r. jedynie 23,2\% pracowników posiadało takie wykształcenie, zaś aż 50,7\% ukończyło jedynie szkołę podstawowa. Wzrastał natomiast poziom upartyjnienia kadr, zwłaszcza po 1948 r., na co wpływało, poza szkoleniami politycznymi, także pochodzenie społeczne $-64,7 \%$ pracowników miało pochodzenie robotnicze, natomiast chłopskie - 19,9\%. Pochodzenia inteligenckiego było jedynie $11,5 \%$ pracowników ${ }^{21}$. Na taki stan rzeczy wpłynęły zmiany zachodzące w Polsce w okresie stalinizmu i nasilającej się ideologizacji w zasadzie wszystkich sfer życia, nie tylko politycznego. Realizowana wówczas akcja czystek w administracji dotknęła także służbę zagraniczna, a nad upartyjnieniem kadr czuwała komisja powołana do zbadania stanu kadrowego w MSZ i Ministerstwie Handlu Zagranicznego. Mechanizm uzależnienia polskiej dyplomacji, jej struktur i kadr od politycznych decyzji KC PZPR w okresie ofensywy ideologicznej ukazuje decyzja podjęta przez Sekretariat KC PZPR (6 X 1949), dotyczaca usunięcia z pracy w Centrali MSZ oraz na placówkach dyplomatycznych i kierowanych przez MHZ osób określanych jako „wrogie i obce elementy”. Nowych pracowników zatrudniano dopiero po uzgodnieniach z Wydziałem Kadr KC PZPR ${ }^{22}$. Kwalifikacje kadr podnoszono podczas trwającej tylko rok nauki w szkole dyplomatycznej i na kursach wieczorowych. Postawy polityczne kształtował nowy system szkoleń ideologicznych. Jednocześnie rozpoczęto wzmacnianie systemu ochrony tajemnicy państwowej oraz bezpieczeństwa budynków placówek dyplomatycznych i konsularnych, realizując w ten sposób stalinowski dekret o ochronie tajemnicy państwowej z 26 X $1949 \mathrm{r}$.

Wraz z postępem procesu międzynarodowego uznawania TRJN przejmował on od rządu londyńskiego sieć placówek dyplomatycznych i konsularnych. 27 IX 1945 r. skierowano do wszystkich placówek zagranicznych okólnik, na mocy którego przejmowano archiwa i mienia placówek konsularnych (urzędowali $\mathrm{w}$ nich dotychczasowi konsulowie ${ }^{23}$. Proces ten nie wszędzie przebiegał bez problemów, które najwyraźniej uwidoczniły się w USA, kiedy we wrześniu 1945 r. Stefan Rogoziński został mianowany konsulem generalnym w Chicago,

\footnotetext{
${ }^{20}$ J. Kukułka, Dyplomacja polska..., s. 572-574.

${ }^{21}$ Ibidem, s. 575.

${ }^{22}$ Ibidem, s. 573-574.

${ }^{23}$ AMSZ, z. 20, w. 1, t. 9, Okólnik nr 6 Departamentu Konsularnego MSZ RP z 27 IX 1945.
} 
a jego poprzednik - konsul Juliusz Szygowski odmówił przekazania konsulatu i zastrzegł, że uczyni to tylko za pośrednictwem przedstawiciela Departamentu $\mathrm{Stanu}^{24}$. Tak też się stało 28 września, kiedy przedstawiciel administracji USA przekazał konsulat Rogozińskiemu. W tym samym czasie przed konsulatem miała miejsce pikieta przeciwników nowej władzy w Polsce, a uczestnicy nieśli tablice z hasłem: „Nie chcemy komunistycznej propagandy”. Miejscowa prasa polonijna także była nastawiona negatywnie do urzędników reprezentujących TRJN i brała udział w organizacji akcji protestacyjnej pod hasłem: „to nie polski to sowiecki konsulat”. W „Dzienniku Związkowym” z 28 września ukazało się oświadczenie gen. Juliusza Szygowskiego z podziękowaniem dla rodaków za współpracę i wyrażającego nadzieję, że „burza, jaka zawisła nad narodem przeminie i będzie on wolny i niepodległy" ${ }^{25}$. Konsulat w Chicago pod nowym kierownictwem przejął pod swoją jurysdykcję okręg zamkniętego konsulatu w San Francisco, a jednocześnie do pracy przyjęto czterech pracowników uprzednio zatrudnionych w konsulacie.

W podobnej atmosferze 28 września przejęto konsulat generalny w Nowym Jorku - symbolicznie klucze wręczył przedstawiciel Departamentu Stanu USA $^{26}$. Brak współpracy czy wręcz bojkot nowych urzędników konsularnych prowadził do chaosu w działaniu placówek pozbawionych podstawowych informacji dotyczących czynności konsularnych, bowiem nie przekazano przedstawicielom TRJN ksiag kasowych, rejestrów wizowych, paszportowych, wojskowych czy nawet pieczęci urzędowych. Natomiast, jak wspominali nowo przybyli urzędnicy konsulatu w Nowym Jorku, musieli oni uregulować zaległe rachunki za wodę, elektryczność i telefony. Pierwsze zadanie konsulatu stanowiło zorganizowanie normalnej pracy urzędowej, co nie było łatwe ze względu na braki kadrowe. Dotychczasowi pracownicy nie chcieli pracować z powodów ideowych lub znaleźli sobie inna pracę w okresie, kiedy nie funkcjonował konsulat. Niemniej jednak w październiku 1945 r. pracę rozpoczęły działy: administracyjny, paszportowo-wizowy i legalizacji, prawny, spraw morskich, spraw poszukiwań. Obsadę kadrową wraz z kierownikiem urzędu Eugeniuszem Rozwadowskim stanowiło w sumie 11 osób. W połowie 1947 r. konsulat zatrudniał już 33 osoby, ale jedynie $7 \mathrm{z}$ nich pracowało

${ }^{24}$ Ibidem, t. 15, Pismo konsulatu gen. w Chicago do chargé d'affaires RP w Waszyngtonie 3 października 1945, k. 2-3. Kwestię działalności polskich placówek dyplomatycznych i konsularnych na terenie USA omawia także Longin Pastusiak w pracy Stosunki polsko-amerykańskie 1945-1955, Toruń 2004, s. 57-64. Ciekawe informacje na temat działalności służby zagranicznej Polski w USA, także w środowiskach polonijnych, zob. Raporty dyplomatyczne Czestawa Miłosza 1945-1950, oprac. M. Morzycka-Markowska, Warszawa 2013.

25 AMSZ, z. 20, w. 1, t. 15, Wycinki prasowe załączone do Pisma Konsulatu Generalego RP w Chicago do chargé d'affaires RP w Waszyngtonie 3 października 1945, k. 2-3.

${ }^{26}$ AMSZ, z. 20, w. 1, t. 15, Pismo Konsula Generalnego w Nowym Jorku gen. Eugeniusza Rozwadowskiego do chargé d'affaires RP W Waszyngtonie 2 X1945, k. 79; ibidem, Sprawozdanie z utworzenia Konsulatu Generalnego RP w Nowym Jorku oraz jego działalność za październik 1945, k. 82-87. 
na etacie, jednocześnie 10 pracowników kontraktowych było obywatelami USA, co dowodzi szybkiej stabilizacji funkcjonowania konsulatu ${ }^{27}$. Po śmierci konsula Rozwadowskiego kierownictwo placówki objął Jan Galewicz. Pod tym kierownictwem konsulat nadal prowadził akcję pomocy materialnej dla polskich pielęgniarek, repatriantów z Meksyku i poszukiwanie osób zaginionych w czasie wojny. Poza rutynowymi czynnościami jak wydawanie wiz, paszportów i legalizacja dokumentów, do zadań konsulatu należała opieka nad polskimi marynarzami z MS Batory i MS Sobieski, nawiązywanie kontaktów z instytucjami kultury, organizacja wyjazdów artystów do Polski oraz koncertów polskiej muzyki w USA. Polscy urzędnicy konsularni zachęcali także Polonię do podróżowania do kraju, podkreślając m.in. ekonomiczne korzyści płynące z tej formy turystyki, dlatego sugerowali Centrali MSZ w Warszawie zwiększenie akcji promocyjnej i propagandowej poprzez druk broszur z informacjami o Polsce.

Przejęcie konsulatu w Pittsburgu nastapiło 12 X 1945 r. ${ }^{28}$ Tam też urzędnicy przybyli z kraju stwierdzili nieład, brak bieżących ksiag kasowych i co więcej, nie posiadali nawet informacji, w którym banku prowadzony był rachunek konsulatu. Nie zważając na problemy, konsul Roman Kwiecień od razu przystapił do nawiązywania kontaktów ze środowiskami opiniotwórczymi i odbył spotkania z dziennikarzami m.in. „Sun-Telegraph” i „Pittsburgh Press”.

Najpóźniej, bo 10 XI 1945 r. został przejęty przez Olgierda Langera konsulat w Detroit. Ten jednak został zmuszony do przeniesienia siedziby konsulatu do pomieszczeń hotelowych, a to na skutek niechęci właściciela budynku, gdzie urzędował, do władz Polski Ludowej. Konsula Langera nie tylko pozbawiono pieczęci i rachunku w banku, ale co gorsza, także instrukcji z kraju i podobnie jak jego koledzy poddany był ostracyzmowi środowisk polonijnych ${ }^{29}$. W konsulacie zatrudniano niewielu pracowników; nawet w 1947 r. liczył tylko 7 pracowników. To mało zważywszy na liczbę spraw, jakimi zajmowali się pracownicy: 214 spraw spadkowych, 161 poszukiwanych osób, 84 sprawy wizowe. Do tego prowadzono działania wśród miejscowych przemysłowców, aby zachęcić ich do uczestnictwa w Międzynarodowych Targach Poznańskich, utrzymywano kontakty z władzami stanowymi i miejskimi oraz jak inne polskie konsulaty prowadzono działalność propagandową na rzecz ziem zachodnich.

Podczas narady, jaka odbyła się Ambasadzie RP w Waszyngtonie, w której uczestniczyli konsulowie RP w USA, dokonano ujednolicenia administracyjnej

${ }_{27}$ AMSZ, z. 6, w. 86, t. 1353, Sprawozdanie z działalności Konsulatu RP w Nowym Jorku za I półrocze 1947, k. 24.

${ }_{28}$ AMSZ, z. 20, w. 1, t. 15, Pismo Kierownika Konsulatu w Pittsburgu Romana Kwietnia do MSZ 12 X 1945, k. 89; ibidem, Pismo Konsulatu RP w Pittsburgu do MSZ 23 X 1945, k. $98-99$.

${ }^{29}$ AMSZ, z. 6, w. 20, t. 1322, Sprawa przejęcia polskich placówek dyplomatycznych w USA, k. 1; ibidem, w. 86, t. 1353, Sprawozdanie z działalności Konsulatu RP w Detroit za I kwartał 1947, k. 1-9. L. Pastusiak, op. cit., s. 59-61. 
Tabela 1. Urzędy Konsularne RP według stanu na listopad 1946 r.

\begin{tabular}{|c|c|c|c|c|}
\hline $\begin{array}{l}\text { Konsulaty } \\
\text { Generalne }\end{array}$ & Konsulaty & $\begin{array}{c}\text { Wydziały } \\
\text { Konsularne }\end{array}$ & $\begin{array}{l}\text { Konsulaty } \\
\text { honorowe }\end{array}$ & $\begin{array}{c}\text { Agencje } \\
\text { konsularne }\end{array}$ \\
\hline $\begin{array}{l}\text { Amsterdam } \\
\text { Bruksela } \\
\text { Chicago } \\
\text { Jerozolima } \\
\text { Kurytyba } \\
\text { Lille } \\
\text { Londyn } \\
\text { Marsylia } \\
\text { Mediolan } \\
\text { New York } \\
\text { Paryż } \\
\text { Stambuł } \\
\text { Tel Aviv }\end{array}$ & $\begin{array}{l}\text { Algier } \\
\text { Detroit } \\
\text { Glasgow } \\
\text { Luksemburg } \\
\text { Lyon } \\
\text { Montreal } \\
\text { Pittsburg } \\
\text { Sao Paulo } \\
\text { Strasburg } \\
\text { Tuluza } \\
\text { Winnipeg }\end{array}$ & $\begin{array}{l}\text { Baden Baden } \\
\text { Bad Salzyflen } \\
\text { Belgrad } \\
\text { Berlin } \\
\text { Berno } \\
\text { Budapeszt } \\
\text { Frankfurt n/M } \\
\text { Helsinki } \\
\text { Kair } \\
\text { Kopenhaga } \\
\text { Meksyk } \\
\text { Moskwa } \\
\text { Nankin } \\
\text { Oslo } \\
\text { Ottawa } \\
\text { Praga } \\
\text { Rio de Janeiro } \\
\text { Rzym } \\
\text { Sofia } \\
\text { Sztokholm } \\
\text { Teheran } \\
\text { Wiedeń }\end{array}$ & $\begin{array}{l}\text { Nicea } \\
\text { Reykjavik } \\
\text { La Valetta }\end{array}$ & $\begin{array}{l}\text { Ancona } \\
\text { Ales } \\
\text { Metz } \\
\text { Perigueux } \\
\text { St. Etienne } \\
\text { Wenecja } \\
\text { Neapol }\end{array}$ \\
\hline
\end{tabular}

Źródło: AMSZ, z. 20, w. 1, t. 7, Sprawozdanie Biura Konsularnego MSZ RP za I półrocze 1946, k. 4-5.

i politycznej pracy polskich placówek dyplomatycznych i konsulatów. Określono także podstawowe kierunki działań na terenie USA: współpraca z Polonia, nawiazanie kontaktów osobistych z jej przedstawicielami, rozwój kontaktów gospodarczych i kulturalnych oraz uzyskanie pomocy dla kraju, w tym prowadzenie akcji przesyłania do Polski przekazów pieniężnych oraz paczek z pomoca.

Akcja przejmowania placówek konsularnych przez przedstawicieli TRJN doprowadziła do poddania jurysdykcji MSZ w Warszawie, w listopadzie 1946 r.: 56 urzędów konsularnych, w tym 3 honorowych i 7 agencji konsularnych ${ }^{30}$. W tym samym czasie na terenie kraju funkcjonowały 24 placówki konsularne państw obcych. Według stanu na sierpień 1948 r. na świecie działały już 64 placówki konsularne $\mathrm{RP}^{31}$. Podane poniżej zestawienie polskich placówek konsularnych zawiera informację o istnieniu trzech konsulatów honorowych, które do stycznia $1949 \mathrm{r}$. zostały zupełnie wyeliminowane z polskiej praktyki konsularnej. Wzorem ZSRR uznano ich istnienie jako przestarzałe, ale najważniejszym powodem była nieufność do konsulów honorowych posiadajacych obce obywatelstwo, szczególnie pochodzacych z krajów kapitalistycznych. Pomimo niskich kosztów działania tego typu placówek oraz możliwości realizacji

\footnotetext{
${ }^{30}$ AMSZ, z. 20, w. 1, t. 7, Wykaz spraw załatwionych w I półroczu 1946, k. 1-3; ibidem, Sprawozdanie Biura Konsularnego MSZ RP za I półrocze 1946, k. 4.

${ }^{31}$ Dz.Urz. MSZ z 1948 r. Nr 8, dodatek - Sieć służby zagranicznej RP.
} 
polskich interesów gospodarczych przez nie, zdecydowano o ich likwidacji i w 1949 r. zamknięto ostatnią polską placówkę w Nicei, uprzednio cofając listy komisyjne wszystkim konsulom honorowym $\mathrm{RP}^{32}$.

Analizując funkcje realizowane przez polskie urzędy konsularne, trudno nie zgodzić się z opinią Mieczysława Majewskiego, że wynikały one nie tylko przepisów prawa czy zwyczaju międzynarodowego, ale były w znacznej mierze efektem specyficznych, powojennych uwarunkowań politycznych, ekonomicznych i międzynarodowych. Dlatego też praca placówek konsularnych w latach 1945-1946 polegała głównie na opiece prawnej i socjalnej nad polskimi obywatelami, prowadzeniu akcji repatriacyjnej i reemigracyjnej, rejestracji obywateli, a także szkód wojennych ${ }^{33}$. Do wymienionych funkcji sukcesywnie dochodziły także te związane z praca wśród Polonii, organizacją życia społecznego i kulturalnego tego środowiska oraz realizacją funkcji gospodarczych i handlowych. Należy podkreślić, że rodzaj spraw, jakimi zajmowali się urzędnicy placówek konsularnych, a także ich natężenie, zależał od specyfiki kraju urzędowania, liczby obywateli polskich oraz Polonii, stanu relacji bilateralnych oraz sytuacji międzynarodowej. W całym omawianym okresie placówki realizowały także rutynowe zadania paszportowe, wizowe, rentowe, spadkowe, notarialne, informacyjne, propagandowe i prowadziły sprawozdawczość.

Tabela 2. Sieć polskiej służby konsularnej według stanu z sierpnia $1948 \mathrm{r}$.

\begin{tabular}{|l|l|l|}
\hline \multicolumn{1}{|c|}{ Siedziba } & Klasa urzędu konsularnego & \multicolumn{1}{|c|}{$\begin{array}{c}\text { Nazwisko kierującego } \\
\text { placówką }\end{array}$} \\
\hline Wiedeń & Wydział Konsularny & Stefan Jaśkiewicz \\
\hline Bruksela & Konsulat Generalny & Kazimierz Szelagowski \\
\hline Antwerpia & Konsulat & Leon Radzikowski \\
\hline Sofia & Wydział Konsularny & Stefan Chanachowicz \\
\hline Praga & Wydział Konsularny & Henryk Pochmarski \\
\hline Bratysława & Konsulat Generalny & Juliusz Znamierowski \\
\hline Ostrawa & Konsulat & Stefan Wengierow \\
\hline Kopenhaga & Wydział Konsularny & Piotr Skuratowicz \\
\hline
\end{tabular}

${ }^{32}$ AMSZ, z. 20, w. 1, t. 2, Pismo Poselstwa RP w Oslo do Biura Konsularnego MSZ 30 I 1947; ibidem, Pismo Poselstwa RP w Sztokholmie do MSZ 15 III 1948, k. 3; ibidem, t. 9, Pismo MSZ do Ministerstwa Przemysłu i Handlu informujące o likwidacji konsulatów honorowych RP 21 V 1948, k. 9. Szerzej na ten temat zob.: S. Sawicki, Konsul honorowy, „Sprawy Międzynarodowe" 1987, z. 6, s. 117-126; Z. Czubiński, Instytucja konsula honorowego $w$ polskim prawie konsularnym i polskiej praktyce, „Zeszyty Naukowe Uniwersytetu Jagiellońskiego. Prace z Nauk Politycznych" 1987, z. 31, s. 7-21; M. Szymura, Instytucja konsula honorowego w praktyce konsularnej Polski XX i XXI wieku, „Studia i Monografie Politechnika Opolska" 2009, z. 244.

${ }^{33}$ M. Majewski, op. cit., s. 137. 


\begin{tabular}{|c|c|c|}
\hline Siedziba & Klasa urzędu konsularnego & $\begin{array}{c}\text { Nazwisko kierującego } \\
\text { placówką }\end{array}$ \\
\hline Helsinki & Wydział Konsularny & Włodzimierz Umiastowski \\
\hline Paryż & Konsulat Generalny & Jan Sukiennik \\
\hline Lille & Konsulat Generalny & Andrzej Kuśniewicz \\
\hline Marsylia & Konsulat Generalny & Tadeusz Łempicki \\
\hline Strasburg & Konsulat & Rudolf Larysz \\
\hline Tuluza & Konsulat & Aleksander Bodak \\
\hline St. Etienne & Agencja Konsularna & Jan Mazgaj \\
\hline Metz & Agencja Konsularna & Wojciech Skrzypek \\
\hline Algier & Konsulat & Marian Ciechanowski \\
\hline Amsterdam & Konsulat Generalny & Leszek Gustowski \\
\hline Heerlen & Agencja Konsularna & vacat \\
\hline Belgrad & Wydział Konsularny & Henryk Zakościelny \\
\hline Zagrzeb & Konsulat Generalny & Tadeusz Budzyński \\
\hline Luksemburg & Konsulat & Józef Chudek \\
\hline Berlin & Wydział Konsularny & Jacek Marecki \\
\hline Düsseldorf & Konsulat Generalny & Kazimierz Janowski \\
\hline Hamburg & Konsulat & Czesław Michalski \\
\hline Hannover & Konsulat & Franciszek Stankowski \\
\hline Frankfurt n/M & Konsulat Generalny & Mieczysław Zambrzuski \\
\hline Monachium & Konsulat & Kazimierz Krukowski \\
\hline Rastatt & Konsulat & Jerzy Krzeczkowski \\
\hline Oslo & Wydział Konsularny & Stanisław Caban \\
\hline Bukareszt & Wydział Konsularny & Stanisław Żyliński \\
\hline Berno & Wydział Konsularny & Stanisław Kalina \\
\hline Genewa & Agencja Konsularna & Feliks Niemira \\
\hline Sztokholm & Konsulat & Piotr Maślankiewicz \\
\hline Götteborg & Agencja Konsularna & Marian Bürtzel-Szuch \\
\hline Budapeszt & Wydział Konsularny & Henryk Kościński \\
\hline Londyn & Konsulat Generalny & Morski Albert \\
\hline Glasgow & Konsulat & Stanisław Teliga \\
\hline Manchester & Agencja Konsularna & Zygmunt Pertyka \\
\hline Southampton & Agencja Konsularna & Stanisław Ziemlewski \\
\hline Rzym & Konsulat Generalny & Piotr Dunin-Borkowski \\
\hline Mediolan & Konsulat Generalny & Edward Asz \\
\hline Wenecja & Agencja Konsularna & Stefan Płoński \\
\hline Moskwa & Wydział Konsularny & Wanda Michalewska \\
\hline Kijów & Konsulat Generalny & Paweł Włoński \\
\hline
\end{tabular}




\begin{tabular}{|c|c|c|}
\hline Siedziba & Klasa urzędu konsularnego & $\begin{array}{c}\text { Nazwisko kierującego } \\
\text { placówką }\end{array}$ \\
\hline Kair & Wydział Konsularny & Witold Skuratowicz \\
\hline Buenos Aires & Wydział Konsularny & vacat \\
\hline Rio de Janeiro & Wydział Konsularny & Rybiński Czesław \\
\hline Sao Paulo & Konsulat Generalny & Franciszek Winnicki \\
\hline Kurytyba & Konsulat & vacat \\
\hline Ottawa & Wydział Konsularny & Władysław Żbik \\
\hline Montreal & Konsulat & Tadeusz Rakowski \\
\hline Winnipeg & Konsulat & Zygmunt Ziemski \\
\hline Mexico City & Wydział Konsularny & Kazimierz Krawczyński \\
\hline Nowy York & Konsulat Generalny & Jan Galewicz \\
\hline Chicago & Konsulat Generalny & Marian Cieplak \\
\hline Pittsburg & Konsulat & Zygmunt Fabisiak \\
\hline Detroit & Konsulat Generalny & Tadeusz Frymar \\
\hline Nankin & Wydział Konsularny & Jan Pianowski \\
\hline Teheran & Wydział Konsularny & Kazimierz Śmiganowski \\
\hline Jerozolima & Konsulat Generalny & Olgierd Górka \\
\hline Tel Aviv & Konsulat Generalny & Rafał Łoc \\
\hline Adamaszek & Konsulat & Jerzy Gutkowski \\
\hline Ankara & Konsulat Generalny & Edward Pawłowski \\
\hline
\end{tabular}

Źródło: Dz.Urz. MSZ z 1948 r. Nr 8, dodatek - Sieć służby zagranicznej RP.

Polska sieć konsularna ulegała zmianom polegajacym na ustanawianiu nowych lub reaktywowaniu starych placówek bądź też na zmianach rodzaju przedstawicielstwa konsularnego. Najczęściej z propozycją utworzenia placówki występowało Biuro Konsularne MSZ bądź też pracownicy służby zagranicznej przebywający w kraju urzędowania, uzasadniając składane wnioski istnieniem dużych skupisk Polaków bądź względami ekonomicznymi. Tak też było w przypadku konsulatu w Southampton, który istniał już przed II wojną światowa i nie zaprzestał działalności podczas jej trwania. Wniosek w sprawie powstania agencji konsularnej w tym mieście motywowany był zarówno względami ekonomicznymi (portowy charakter miasta, możliwość obserwacji obrotu morskiego, możliwości rozwoju polskiej polityki morskiej), jak też odnosił się do spraw reemigracji do kraju zdemobilizowanych żołnierzy i ludności cywilnej, wracajacych do $\mathrm{kraju}^{34}$. Podobnie argumentowano konieczność ponownego utworzenia

${ }^{34}$ AMSZ, z. 20, w. 38, t. 452, Wniosek Biura Konsularnego MSZ w sprawie utworzenia w Southampton agencji konsularnej w miejsce konsulatu honorowego 9 I 1947, k. 1; ibidem, Zarządzenie Ministra Spraw Zagranicznych z 15 III 1947 w sprawie ustanowienia Agencji Konsularnej w Southampton z dniem 1 IV 1947, k. 2. 
placówki konsularnej w Antwerpii (likwidowanej w sierpniu 1946 r.), która realizowałaby polskie interesy morskie, ułatwiała kontakt z załogami statków i stwarzała szansę na kontakty z przedstawicielami 24 urzędów konsularnych innych państw ${ }^{35}$. Interesy gospodarcze oraz konieczność opieki nad 24 tys. polskich żołnierzy spowodowały rozbudowę sieci konsularnej na terenie Włoch. Biuro Konsularne MSZ zwracało uwagę na konieczność utworzenia urzędu w Genui, zajmującego się załogami statku MS Sobieski, wpływającego do tego portu. Placówka straciła rację bytu po likwidacji połaczenia Genua-Ameryka Północna i sprzedaży statku. Z kolei względy współpracy gospodarczej i kulturalnej, dobre relacje z komunistycznymi władzami Wenecji oraz skupisko polonijne miały zdecydować o powstaniu tam konsulatu. Z drugiej strony zakończenie akcji rejestracji Polaków we Włoszech oraz poważne braki kadrowe doprowadziły do zamknięcia 1 XI 1947 r. wicekonsulatu w Neapolu (podniesionego od 1 I 1947 r. z agencji konsularnej do wicekonsulatu).

Jak wspomniano, poza rutynowymi działaniami placówek konsularnych, realizowały one zadania wynikajace ze specyfiki sytuacji w kraju urzędowania oraz warunków życia mieszkających tam Polaków. W związku z dużym wychodźstwem polskim we Francji i Belgii polskie placówki zajmowały się głównie prowadzeniem akcji reemigracji Polaków oraz opieką prawną i społeczna. Reaktywowane już w 1945 r. placówki na terenie Francji należały do najliczniejszych, usytuowanych w jednym kraju urzędowania, ale też zatrudniających relatywnie dużo pracowników. Konsulat Generalny RP w Paryżu, kierowany przez Tomasza Piętkę, zatrudniał 31 osób, konsulat w Lille liczył 20 pracowników, a ponadto planowano wzmocnienie kadrowe placówek w Metz, Alès, Charleville, gdzie znajdowały się obozy dla deportowanych. Przejęto także placówkę w Algierze oraz oczekiwano na urząd w Casablance, co miało szczególne znaczenie z uwagi na przebywających w Afryce Północnej ok. 2000 Polaków, głównie narodowości żydowskiej ${ }^{36}$.

Personel placówek we Francji często wywodził się ze środowisk polskiej emigracji, bowiem liczono na jej lepsze kontakty z Polonią i przez to także na lepszą opiekę nad Polakami. Szczególne zainteresowanie okazywano polskim obywatelom, którzy znaleźli się we Francji, Belgii i Szwajcarii, na skutek działań wojennych i to właśnie na ich powrót do Polski oczekiwano. Natomiast starszą emigrację ledwie otaczano opieką konsularną ${ }^{37}$. Działania urzędów konsularnych we Francji w dużej mierze koncentrowały się na pracy

${ }^{35}$ Ibidem, t. 453, Pismo Poselstwa RP w Brukseli do MSZ RP 23 I 1947.

${ }^{36}$ Ibidem, t. 456, Pismo Ambasady RP w Paryżu w sprawie uruchomienia placówek konsularnych na terenie Francji 4 XII 1945, k. 21-22; P. Sękowski, Działalność przedstawicielstw dyplomatycznych $i$ konsularnych władz warszawskich Rzeczypospolitej Polskiej we Francji w latach 1944-1947, „Dzieje Najnowsze” R. XLIV, 2012, nr 3, s. 99-101.

37 AMSZ, z. 20, w. 38, t. 456, k. 2, Sprawozdanie z kontroli przeprowadzonej przez Zygmunta Tarło-Mazińskiego w placówkach konsularnych we Francji, Belgii, Szwajcarii w styczniu 1946, k. 2. 
w środowisku polonijnym: opiece nad szkolnictwem, dokształcaniu nauczycieli, tworzeniu przedszkoli oraz na sprawach rentowych, spadkowych, zapomogach dla żołnierzy i inwalidów wojennych, wydawaniu zaświadczeń obywatelstwa ${ }^{38}$. Pracownicy konsulatów starali się nawiązać do przedwojennych tradycji polskich placówek we Francji opiekujących się polskim wychodźstwem, jednak nie było to łatwe z uwagi na niechęć wielu Polaków do władz komunistycznych w kraju oraz silne wpływy księży z Polskiej Misji Katolickiej w Paryżu.

W szczególnych warunkach przyszło działać służbom konsularnym RP na terenie stref okupacyjnych Niemiec. W latach 1946-1949 funkcjonował tam Wydział Konsularny przy Polskiej Misji Wojskowej w Berlinie oraz otwarto konsulaty generalne we Frankfurcie n/M, Düsseldorfie oraz konsulaty w Hamburgu, Hanowerze, Monachium i Rastatt ${ }^{39}$. Kierownikiem Wydziału Konsularnego PMW był Kazimierz Libera, znawca prawa międzynarodowego i zwolennik reemigracji Polaków do kraju, także przedwojennej emigracji. Działania Wydziału koncentrowały się na realizacji funkcji opiekuńczych wobec polskich obywateli, wśród których prowadzono także akcję rejestracyjna, przedłużano wizy i paszporty. Codziennie do Wydziału zgłaszało się ok. 200 interesantów, a wśród repatriantów dominowali robotnicy przymusowi i więźniowie obozów. Dzięki staraniom Wydziału do końca 1946 r. zorganizowano powrót do kraju 1540 osób znajdujących się w radzieckiej strefie okupacyjnej. Wiosna 1948 r. rozpoczęto akcję repatriacji ze strefy brytyjskiej 5,5 tys. osób. Wydział prowadził działalność w skrajnie skomplikowanych warunkach, jakie istniały w okupowanych Niemczech, ale pomimo tego pomógł w powrocie do kraju ok. 15 tys. Polaków.

Trudne i specyficzne warunki pracy polskiej służby konsularnej istniały także na terenie ZSRR. Pomimo sojuszniczych relacji z Polska, władze radzieckie nie realizowały zapowiedzi stworzenia warunków dla powstania sieci polskich placówek konsularnych, kiedy tymczasem na terenie Polski funkcjonowały konsulaty w Poznaniu, Krakowie i Gdańsku oraz Wydział Konsularny Ambasady ZSRR w Warszawie. W praktyce konsularnych relacji między państwami socjalistycznymi dość powszechnie panowało przekonanie, że kwestie mniejszości narodowych są wewnętrzną sprawą kraju urzędowania, natomiast urzędnicy, których zadanie stanowiła opieka nad rodakami, często nie realizowali tej podstawowej funkcji ${ }^{40}$. Tak było też $\mathrm{w}$ przypadku władz

${ }^{38}$ Ibidem, Protokół z kontroli działalności Konsulatu Generalnego RP w Paryżu przeprowadzonej w dniach 9-18 VI 1946, k. 130; ibidem, Sprawozdanie ze zjazdu konsularnego w Lille 22-24 II 1946, k. 45-59.

${ }^{39}$ Ibidem, Pismo szefa Polskiej Misji Wojskowej w Berlinie do MSZ 14 IX 1946, k. 5-6; P. Czaplicki, Zarys działalności Wydziału Konsularnego Polskiej Misji Wojskowej w Berlinie w latach 1946-1949, „Przegląd Zachodni” 2004, nr 1, s. 94-109.

${ }^{40}$ Podobnie wyglądała sytuacja w odniesieniu do polskich placówek konsularnych w Czechosłowacji. Por. A. Szczepańska, Warszawa-Praga 1948-1968. Od nakazanej przyjaźni do kryzysu, Szczecin 2011, s. 102-116. 
radzieckich, które nie życzyły sobie ingerowania w relacje z Polakami przebywającymi na terenie ZSRR, należy dodać, że najczęściej wbrew swojej woli. Strona polska zamierzała otworzyć konsulaty w Kijowie (powstał tu w 1948 r.), Mińsku oraz Wilnie (w 1948 r. powstał formalnie, ale nie rozpoczą działalności), jednak praca konsularna koncentrowała się w Wydziale Konsularnym Ambasady RP w Moskwie ${ }^{41}$. Jego szefem był Leon Pohoryles i zważywszy na ogrom pracy, stan zatrudnienia - początkowo 9 osób, a w 1947 r. - 13, należy uznać za dalece niewystarczajacy. Referat Prawny Wydziału porządkował wykaz ok. 20 tys. polskich obywateli na terenie ZSRR i jak wcześniej wspomniano, nie było to łatwe nie tylko z powodu wojennego chaosu, ale też braku dobrej woli władz radzieckich, niechętnie wydających dokumenty. Do tego interwencje prowadzone $\mathrm{w}$ sprawach Polaków u władz radzieckich były najczęściej bezskuteczne. Zajmowano się także repatriacją do Polski i udzielaniem porad prawnych, wydobywano dokumenty stanu cywilnego, dyplomy w imieniu osób zamieszkujacych kiedyś ziemie utracone na rzecz ZSRR ${ }^{42}$.

Do jednych z najstarszych funkcji konsularnych należy ochrona interesów gospodarczych i handlowych państwa. Tymczasem właśnie na tle podziału kompetencji w odniesieniu do realizacji czynności gospodarczych przez urzędu konsularne powstał spór kompetencyjny, którego stronami stały się Ministerstwo Spraw Zagranicznych oraz Ministerstwo Żeglugi i Handlu. W strukturach polskiej służby zagranicznej funkcjonowały Biura Radców Handlowych, którzy merytorycznie i budżetowo podlegali resortowi żeglugi i handlu zagranicznego, natomiast służbowo szefom placówek dyplomatycznych. Tym samym ograniczono samodzielność konsulów w odniesieniu do realizacji czynności gospodarczych i morskich, które mogli wykonywać jedynie za zgodą radców handlowych i wiedzą szefa placówki. Na radców natomiast nałożono obowiązek informowania kierowników urzędów o swojej działalności oraz współpracy z konsulami w obronie interesów gospodarczych Polski ${ }^{43}$.

Konsulom RP pozostawiono kompetencje morskie, uzasadniając konieczność ich wzmocnienia realizacja planu sześcioletniego, którego efektem miało być uczynienie z Polski kraju morskiego oraz „przestawienie służby zagranicznej RP na służbę państwa morskiego”, a także „marynizacja handlu

${ }^{41}$ AMSZ, z. 20, w. 38, t. 453, Pismo Biura Konsularnego do Biura Personalnego MSZ 6 VI 1947, k. 42-43. Na powstanie polskich konsulatów nie wpłynęło pozytywnie nawet podpisanie konwencji konsularnej w 1958 r. Dopiero na poczatku lat 70. władze radzieckie pozwoliły na otwarcie konsulatów w Mińsku i Leningradzie. Szerzej na temat powstania i działalności placówek konsularnych RP na terenie ZSRR zob. M. Golon, op. cit., s. 201-237.

${ }^{42}$ AMSZ, z. 20, w. 1, t. 7, Sprawozdanie Biura Konsularnego MSZ RP za luty 1947, k. 24-42.

${ }^{43}$ Ibidem, w. 38, t. 453, Pismo ministra Stefana Jędrychowskiego do Ministra Spraw Zagranicznych; ibidem, w. 1, t. 15, Okólnik nr 3 ministra Z. Modzelewskiego 25 I 1947, k. 126-127; Dz.Urz. MSZ z 1947 r. Nr 1 poz. 2, Zasady współdziałania radców handlowych z kierownikami urzędów konsularnych RP 31 XII 1946; K. Libera, Prawo konsularne..., cz. 2, s. $15-18$. 
zagranicznego"44. Morskie uprawnienia administracyjno-prawne konsulów polegały na opiece nad okrętami podczas pobytu na obcych wodach, ochronie słuszności bandery, zabezpieczeniu statków przed zagrożeniami podczas postoju w porcie, zastępstwie przed władzami sądowymi i administracyjnymi w sprawach dotyczących okrętów i ładunków. Konsul miał też obowiązek informowania o przepisach dotyczących świadectw pochodzenia towarów oraz czuwać nad ich stosowaniem, a także wizował świadectwa potwierdzające kraj pochodzenia towaru, wystawione przez Izby Przemysłowo-Handlowe lub instytucje handlowe, a nie przez władze celne ${ }^{45}$. Obowiazki w zakresie sprawozdawczości urzędów konsularnych nakładały na nie obowiązek informowania o sytuacji gospodarczej kraju urzędowania oraz możliwościach rozwoju wymiany handlowej ${ }^{46}$.

Reasumując, należy wskazać na znaczący spadek liczby urzędów konsularnych RP w porównaniu nie tylko z okresem międzywojennym, ale także z rokiem 1945. Tendencja do odchodzenia od utrzymywania urzędów konsularnych w relacjach PRL z zagranica była widoczna także w następnych latach (50 urzędów konsularnych w 1973 r. ${ }^{47}$ ). Braki kadrowe, a także poszukiwanie oszczędności w postaci rezygnacji z dzierżawy budynków, zmniejszanie zatrudnienia czy zmiany statusu personelu placówek zagranicznych powodowały zamykanie placówek konsularnych ${ }^{48}$. Jednocześnie wzrastała liczba przedstawicielstw dyplomatycznych, Biur Radców Handlowych czy Ośrodków Informacyjnych, realizujących coraz więcej funkcji gospodarczych, kulturalnych, naukowych, jakimi tradycyjnie zajmowały się konsulaty. Do tego należy dodać fakt rezygnacji przez władze polskie z prowadzenia honorowych przedstawicielstw konsularnych. Funkcje realizowane przez polskie placówki konsularne, poza administracyjno-urzędowymi, były warunkowane powojenna sytuacją oraz celami polityki zagranicznej wyznaczonymi przez kierownictwo partii komunistycznej zdobywającej monopol władzy. W omawianym okresie polegały one na prowadzeniu akcji opiekuńczej wobec polskich obywateli, repatriacji i reemigracji, rejestracji szkód wojennych oraz działaniach mających na celu pozyskanie Polonii (często przy wykorzystaniu propagandy skierowanej przeciwko władzom polskim w Londynie). Pomimo oczywistego wpływu władz komunistycznych na struktury i formy pracy urzędów konsularnych RP,

\footnotetext{
${ }^{44}$ AMSZ, z. 20, w. 1, t. 15, Uzasadnienie dla czynności zagranicznych konsulów, k. 133.

${ }^{45}$ Ibidem, w. 15, t. 140, Informacja MSZ na temat podziału kompetencji urzędów zagranicznych RP w zakresie działalności gospodarczej, k. 37-38.

${ }^{46}$ Dz.Urz. MSZ z 1946 r. Nr 2 poz. 29, Kwartalne sprawozdania administracyjne urzędów konsularnych 20 II 1946.

${ }^{47}$ K. Szczepanik, Wybrane zagadnienia..., s. 31-33.

${ }^{48}$ Szerzej na temat akcji „O” polegającej na poszukiwaniu oszczędności w służbie zagranicznej zob.: AMSZ, z. 20, w. 75, t. 970, Pismo Konsulatu Generalnego RP w Londynie do Biura Konsularnego MSZ w związku z likwidacją placówki w Glasgow 21 IV 1950, k. 4; ibidem, Akt zniesienia Konsulatu Generalnego w Amsterdamie, k. 21.
} 
warto wspomnieć także o pozytywnych stronach ich działalności w okresie tak trudnym. Do nich niewątpliwie należą pomoc tysiącom Polaków w powrocie do kraju, w uzyskaniu rent, emerytur, odszkodowań, spadków czy wreszcie działania na rzecz poszukiwania osób zaginionych w czasie wojny. Pierwszy, omawiany okres powojennej działalności polskich urzędów konsularnych charakteryzował się także wysokim stopniem zaangażowania w sprawy opieki nad polskim obywatelami w krajach socjalistycznych, z czasem odsuwajacc na dalszy plan tę najstarszą funkcję konsulatów.

\section{Streszczenie}

Funkcje realizowane przez polskie placówki konsularne w latach 1945-1949 (poza rutynowymi administracyjno-urzędowymi) były warunkowane powojenną sytuacja, brakami kadrowymi oraz celami polityki zagranicznej wyznaczonymi przez kierownictwo partii komunistycznej. W omawianym okresie polegały one na prowadzeniu akcji opiekuńczej wobec polskich obywateli, repatriacji i reemigracji, rejestracji szkód wojennych oraz działaniach mających na celu pozyskanie Polonii (często przy wykorzystaniu propagandy skierowanej przeciwko władzom polskim w Londynie). Pomimo oczywistego wpływu władz komunistycznych na struktury i formy pracy urzędów konsularnych RP, warto wspomnieć także o pozytywnych stronach ich działalności w okresie tak trudnym. Do nich niewątpliwie należą pomoc tysiacom Polaków w powrocie do kraju, w uzyskaniu rent, emerytur, odszkodowań, spadków czy wreszcie działania na rzecz poszukiwania osób zaginionych w czasie wojny. Pierwszy, omawiany okres powojennej działalności polskich urzędów konsularnych charakteryzował się także wysokim stopniem zaangażowania w sprawy opieki nad polskim obywatelami w krajach socjalistycznych, z czasem tracąc z pola widzenie tę najstarszą funkcję konsulatów. Fakt ten, jak i ograniczenie gospodarczych i handlowych funkcji konsula, był efektem wprowadzania wzorców radzieckich do organizacji polskiej służby zagranicznej po II wojnie światowej.

\section{Organization and functioning of the Polish consular service in 1945-1949}

Functions performed by Polish consular posts in 1945-1949 (apart from standard administrative and official ones) were conditioned by the post-war situation, staff shortage, and by goals of foreign policy set by the leaders of the communist party. In the analysed period they consisted in caring for Polish citizens, repatriation and re-emigration operations, registration of war damages, and actions aiming at gaining the Polonia (often with the use of propaganda against the Polish governments in London). It is worthy of notice that, despite obvious influence of the communist authorities on the structures and forms of work of Polish consular offices at that time, there were also some positive aspects of their operations, such as, undoubtedly, their help to thousands of Poles in coming back to Poland, in getting old-age or disability pensions, compensations, inheritances, or their actions on behalf of searching people who went missing during the war. The initial years of the analysed period of post-war operations of Polish consular offices were characterised also by a strong commitment to the problems of assistance for Polish citizens in socialist countries, but with the lapse of time this function of consulates was becoming less and less important. This, together with some limitations of economic and commercial functions of the consul, resulted from the introduction of Soviet models into the structure of Polish foreign services after the World War Second. 


\section{Bibliografia}

Bertoni K., Praktyka dyplomatyczna i konsularna, Kraków 1947.

Czaplicki P., Zarys działalności Wydziału Konsularnego Polskiej Misji Wojskowej w Berlinie w latach 1946-1949, „Przegląd Zachodni” 2004, nr 1.

Czubiński Z., Instytucja konsula honorowego w polskim prawie konsularnym i polskiej praktyce, „Zeszyty Naukowe Uniwersytetu Jagiellońskiego. Prace z Nauk Politologicznych” 1987, z. 31.

Gabryelska-Straburzyńska B., Umowy konsularne w trzydziestoleciu Polski Ludowej, „Sprawy Międzynarodowe" 1975, z. 11.

Golon M., Moskwa, Kijów, Mińsk, Leningrad, Wilno... Problem utworzenia i działalności polskich placówek konsularnych w ZSRR w latach 1944-1972, w: Polska polityka wschodnia w XX wieku, red. M. Wojciechowski, Z. Karpus, Włocławek-Toruń 2000.

Historia dyplomacji polskiej, t. VI: 1944/1945-1989, red. W. Materski, M. Michowicz, Warszawa 2010.

Kukułka J., Dyplomacja polska w latach 1944-1989, w: Historia dyplomacji polskiej X-XX w., red. G. Labuda, W. Michowicz, Warszawa 2000.

Kukułka J., Organizacja polskiej stużby konsularnej w latach 1944-1989, „Stosunki Międzynarodowe" 2000, nr 1-2.

Libera K., Prawo konsularne, cz. 1-2, Warszawa 1951.

Libera K., Zasady międzynarodowego prawa konsularnego, Warszawa 1960.

Majewski M., Stużba konsularna Polski Ludowej, „Sprawy Międzynarodowe” 1975, z. 11.

Pałyga E.J., Stosunki konsularne Drugiej Rzeczypospolitej, Warszawa 1970.

Pastusiak L., Stosunki polsko-amerykańskie 1945-1955, Toruń 2004.

Podstawy prawno-organizacyjne stosunków PRL z zagranica, red. M. Frankowska, WrocławWarszawa-Kraków 1983.

Sawicki S., Konsul honorowy, „Sprawy Międzynarodowe” 1987, z. 6.

Sawicki S., Podstawy prawne funkcji konsularnych, PISM, na prawach rękopisu, Warszawa 1989.

Sawicki S., Podstawy prawne funkcji konsularnych, „Sprawy Międzynarodowe” 1990, z. 3.

Sękowski P., Dziatalność przedstawicielstw dyplomatycznych $i$ konsularnych wtadz warszawskich Rzeczypospolitej Polskiej we Francji w latach 1944-1947, „Dzieje Najnowsze” R. XLIV, 2012, nr 3.

Sutor J., Funkcje konsularne w zakresie obrotu prawnego z zagranica, „Palestra” 1978, nr 9. Szczepanik K., Dyplomacja Polski 1918-2000. Struktury organizacyjne, Warszawa 2000.

Szczepanik K., Wybrane zagadnienia z zakresu ewolucji struktur organizacyjnych polskiej stużby dyplomatyczno-konsularnej w latach 1944-1989, w: Historia dyplomacji polskiej, t. VI: 1944/1945-1989, red. W. Materski, W. Michowicz, Warszawa 2010.

Szczepańska A., Warszawa-Praga 1948-1968. Od nakazanej przyjaźni do kryzysu, Szczecin 2011.

Szymura M., Instytucja konsula honorowego w praktyce konsularnej Polski XX $i$ XXI wieku, „Studia i Monografie Politechniki Opolskiej” 2009, z. 244.

Bi o g r a m: Anna Szczepańska-Dudziak - profesor Uniwersytetu Szczecińskiego, zajmuje się polską polityką zagraniczną i dyplomacja. Zainteresowania badawcze koncentruja się wokół relacji polsko-czechosłowackich/ czeskich oraz ewolucji form dyplomatycznych w XXXXI wieku. E-mail: szczepanska.anna@whus.pl. 